\title{
Electrochemical As(III) whole-cell based biochip sensor
}

\author{
Fernando Cortés-Salazar ${ }^{\mathrm{a}}$, Siham Beggah ${ }^{\mathrm{b}}$, Jan Roelof van der Meer ${ }^{\mathrm{b}}$, Hubert H. Girault ${ }^{\mathrm{a}, *}$ \\ a Laboratoire d'Electrochimie Physique et Analytique, Ecole Polytechnique Fédérale de Lausanne, Station 6, CH-1015 Lausanne, Switzerland \\ ${ }^{\mathrm{b}}$ University of Lausanne, Department of Fundamental Microbiology, Bâtiment de Biologie, CH-1015 Lausanne, Switzerland
}

\section{A R T I C L E I N F O}

\section{Article history:}

Received 3 December 2012

Received in revised form

20 February 2013

Accepted 4 March 2013

Available online 20 March 2013

Keywords:

Arsenite

Bacterial bioreporter

Electrochemical read-out

\begin{abstract}
A B S T R A C T
The development of a whole-cell based sensor for arsenite detection coupling biological engineering and electrochemical techniques is presented. This strategy takes advantage of the natural Escherichia coli resistance mechanism against toxic arsenic species, such as arsenite, which consists of the selective intracellular recognition of arsenite and its pumping out from the cell. A whole-cell based biosensor can be produced by coupling the intracellular recognition of arsenite to the generation of an electrochemical signal. Hereto, E. coli was equipped with a genetic circuit in which synthesis of beta-galactosidase is under control of the arsenite-derepressable arsR-promoter. The E. coli reporter strain was filled in a microchip containing 16 independent electrochemical cells (i.e. two-electrode cell), which was then employed for analysis of tap and groundwater samples. The developed arsenic-sensitive electrochemical biochip is easy to use and outperforms state-of-the-art bacterial bioreporters assays specifically in its simplicity and response time, while keeping a very good limit of detection in tap water, i.e. $0.8 \mathrm{ppb}$. Additionally, a very good linear response in the ranges of concentration tested $\left(0.94 \mathrm{ppb}\right.$ to $3.75 \mathrm{ppb}, R^{2}=0.9975$ and 3.75 $\mathrm{ppb}$ to $30 \mathrm{ppb}, R^{2}=0.9991$ ) was obtained, complying perfectly with the acceptable arsenic concentration limits defined by the World Health Organization for drinking water samples (i.e. $10 \mathrm{ppb}$ ). Therefore, the proposed assay provides a very good alternative for the portable quantification of As (III) in water as corroborated by the analysis of natural groundwater samples from Swiss mountains, which showed a very good agreement with the results obtained by atomic absorption spectroscopy
\end{abstract}

(c) 2013 Elsevier B.V. All rights reserved.

\section{Introduction}

Toxicity of arsenic to humans has been known for centuries, (Eisler, 1988) however the interest on this topic is still very active worldwide and intense efforts are devoted to the detection of arsenic species and mitigation of their associated toxicity (Beauchamp et al., 2011; De la Calle et al., 2011; Jomova et al., 2011; Wan et al., 2011). Arsenic occurs naturally mainly in form of sulfide ores that, depending on the biogeochemical conditions can release toxic inorganic species in groundwater, such as arsenate (V) and arsenite (III). However, arsenic species might also be released from certain Ascontaining pesticides, and from mining or smelting activities, leading to the contamination of water sources and food. According to the World Health Organization (WHO) long periods of exposition to arsenic (III) concentrations higher than $10 \mu \mathrm{g} / \mathrm{L}$ (or $10 \mathrm{ppb}$ ) can cause harmful effects to human health, such as skin lesions, peripheral neuropathy, diabetes, renal system effects, cardiovascular disease and cancer (WHO, 2010). Therefore, most European countries and North America have taken $10 \mu \mathrm{g} / \mathrm{L}$ of arsenite as the highest acceptable concentration of arsenic in drinking water. However, in countries like

\footnotetext{
* Corresponding author. Tel.: +41 21693 3145; fax: +41 216933667.

E-mail address: hubert.girault@epfl.ch (H.H. Girault).
}

Bangladesh a higher threshold value of $50 \mu \mathrm{g} / \mathrm{L}$ is currently employed. High concentrations of arsenic in groundwater can be found in almost every continent, affecting countries such as Canada, United States of America, Argentina and more drastically Bangladesh (Brunt et al., 2004). Recently, it has been shown that in some Swiss regions the content of arsenic-rich ores is leading to elevated concentrations of soluble arsenic in groundwater (Pfeifer et al., 2004).

According to the ASTM (ASTM D2972-08), the determination of arsenic in water should be performed by two techniques, namely colorimetry or atomic absorption spectroscopy (AAS). Despite that colorimetry is very simple, can be performed with portable instruments and is not expensive, it leads to a high proportion of false positive results, which limits its use. In addition, colorimetric methods often base on the generation of arsine gas and employ other toxic metals (Melamed, 2005; Rahman et al., 2002). AAS and induced coupled plasma mass spectrometry (ICP-MS) are probably the most widely used techniques for arsenic detection with limits of detection (LOD) in the low ppb range ( $1 \mathrm{ppb}$ for AAS and $0.5 \mathrm{ppb}$ for ICP-MS) (Melamed, 2005). Unfortunately, both AAS and ICP-MS are not easily portable and require use of expensive instrumentation. Anodic stripping voltammetry is perhaps one of the most sensitive reported technique for arsenic quantification ( $\mathrm{LOD}=0.05 \mathrm{ppb})$, but it is susceptible to interferences with copper, lead or mercury, among other cations commonly present in water samples (Feeney and Kounaves, 
2002; Melamed, 2005). More recently, portable and sensitive (LOD =1-1.6 ppb) (Buffi et al., 2011) whole-cell biosensors have been developed showing a very high selectivity (only antimonite and arsenate present a positive interference), which provide a bioavailable rather than total concentration (Buffi et al., 2011; Melamed et al., 2012; Scott et al., 1997; Stocker et al., 2003; Tauriainen et al., 1997, 1998; Trang et al., 2005). Whole-cell bacterial biosensors for arsenic rely on the natural arsenic resistance mechanism, which is transduced into the de novo formation of a spectroscopically or electrochemically active protein (Daunert et al., 2000; Ron, 2007; Van Der Meer and Belkin, 2010; Van Der Meer et al., 2004). Arsenic resistance relies on the ars operon, which in case of plasmid R773 encodes five different proteins, ArsA, ArsB, ArsC, ArsD and ArsR. ArsA and B form a pump that actively removes arsenite from the cell, whereas ArsC is a reductase that can reduce arsenate to arsenite, and ArsD is a coupling protein presenting arsenite to the ArsAB pump. Finally, the expression of the ars operon is controlled specifically by ArsR, which represses ars transcription in the absence of arsenite by binding the DNA at specific binding sites and obstructing the RNA polymerase. In presence of arsenite (or antimonite), the ArsR protein loses affinity for the DNA binding sites as a result of a conformational change upon binding of arsenite to it (Daunert et al., 2000). Importantly, reporter cells not only react to $\mathrm{As}(\mathrm{III})$, but to $\mathrm{As}(\mathrm{V})$ as well, but with a five-fold lower response at the same concentration (Baumann and Van Der Meer, 2007). For this reason, the response of the cells to unknown samples and inferred from calibration standards using As(III) should be referred to as "arsenite-equivalent concentrations". To transduce arsenic detection in the bacterial cell into a readable signal, a reporter gene that encodes a reporter protein is brought under control of ArsR, such as LacZ that encodes for $\beta$ galactosidase $(\beta-\mathrm{Gal})$. In that case the cell will produce reporter protein ( $\beta$-Gal) when it encounters arsenite or arsenate. $\beta$-Gal has been employed as reporter protein in many bacterial bioreporters, since it allows for reproducible and quantitative detection by different means. For instance, when using p-aminophenyl $\beta$-Dgalactopyranoside (PAPG) as substrate for $\beta$-Gal p-aminophenol (PAP) is produced, which is easily detectable by electrochemical means (see Fig. 1). An early report of such strategy was presented in 1997 by Scott et al. where an electrochemical read out of a bacterial bioreporter was developed and optimized for the detection of antimonite and arsenite with limits of detection close $1 \times 10^{-7} \mathrm{M}$ (Scott et al., 1997). However, in order to reach such a high sensitivity not only a long induction process was required (i.e. $17 \mathrm{~h}$ ), but also a long subsequent detection process that included cell lysis, $\beta-\mathrm{Gal}$ extraction and purification, enzymatic reaction with PAPG at $37^{\circ} \mathrm{C}$ (optimum enzymatic reaction temperature) and electrochemical detection of PAP in a separated electrochemical cell $(>2.5 \mathrm{~h})$. (Scott et al., 1997). Despite following reports that based bioreporter output on fluorescence or chemiluminescence, (Buffi et al., 2011; Ramanathan et al., 1997, 1998; Stocker et al., 2003) electrochemical read-out provides several advantages such as: (i) fast, sensitive and reproducible recorded signal, (ii) $\mathrm{O}_{2}$ independent measurements (unlike some fluorescence and luminescence systems that requires $\mathrm{O}_{2}$ to emit light), (iii) quantification in systems with suspended particles, (iv) easy to multiplex and miniaturize, (v) in situ and online measurements and (vi) no perturbations of the read-out by the metabolism of the bacteria (it does not require any additional energy consumption) (Popovtzer et al., 2005; Ron and Rishpon, 2010).

Here, we have revisited the electrochemical read-out of arsenic sensitive bioreporters to show that faster, simpler and very sensitive detection of arsenite can be achieved by integrating the reporter cells on microchips. For instance, in situ detection of PAP can be performed thanks to the free transport of PAPG and PAP through the cell membrane (see Fig. 1, step IV), avoiding time consuming steps such as cell lysis, extraction and purification of reporter proteins and noncharged redox species, as shown recently for other whole cell based sensors (Badihi-Mossberg et al., 2007; Biran et al., 1999, 2000; Neufeld et al., 2006; Paitan et al., 2004; Popovtzer et al., 2005; Popovtzer et al., 2006). As a result, the complete biosensing assay can be performed inside a single disposable microchip containing 16 independent electrochemical cells for the in situ monitoring of $\beta$-Gal activity produced by an Escherichia coli arsenic sensitive bioreporter within 25 min-50 min for $7.5 \mathrm{ppb}$ As (III), in comparison to other arsenic sensitive bacterial bioreporters and with a high sensitivity ( $\mathrm{LOD}=0.8 \mathrm{ppb}$ ) (vide infra). Multiple sample analysis in series can further reduce the effective time for a single analysis to $10 \mathrm{~min}$ or less (Siegfried et al. 2012). Moreover, we validated the present methodology by comparing the bioreporter assay response with atomic absorption spectroscopy (AAS) on arsenic contaminated groundwater samples from Swiss mountain areas and from Romania.

\section{Experimental section}

\subsection{Chemicals}

4-Aminophenyl-beta-D-galactopyranoside (PAPG, Biosynth, Thal, Switzerland), $\mathrm{NaCl}$ ( $\geq 99 \%$, Buchs, Sigma, Switzerland), $\mathrm{KCl}(\geq 99 \%$,

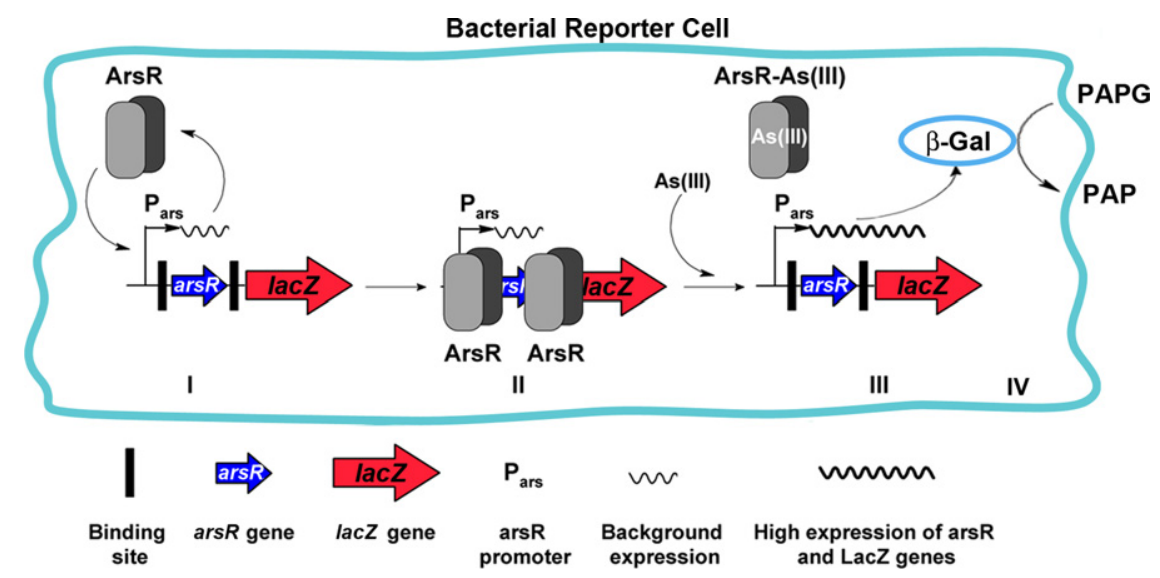

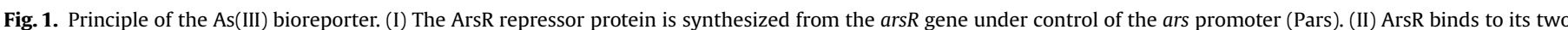

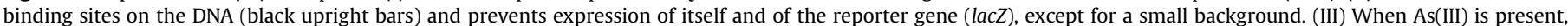

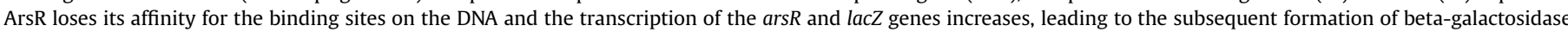

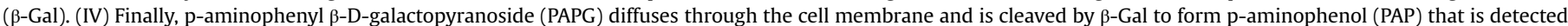
electrochemically outside the cell. 
Buchs, Sigma, Switzerland), $\mathrm{Na}_{2} \mathrm{HPO}_{4} \cdot 2 \mathrm{H}_{2} \mathrm{O}$ (Buchs, Sigma, Switzerland), $\mathrm{KH}_{2} \mathrm{PO}_{4}$ (Buchs, Sigma, Switzerland) and sodium pyrophosphate solution $\left(\mathrm{Na}_{4} \mathrm{P}_{2} \mathrm{O}_{7} \cdot 10 \mathrm{H}_{2} \mathrm{O}\right.$, Buchs, Sigma, Switzerland) were used as received. Deionized water was produced by a Milli-Q plus 185 model from Millipore (Zug, Switzerland).

\subsection{Electrochemical measurements}

All electrochemical measurements were performed with commercially available microchips (Diagnoswiss S.A., Switzerland). Each disposable microchip contains 16 independent twoelectrode cells, with a working electrode made of gold and a counter-reference electrode made of silver. The electrochemical setup is completed by a well ( $50 \mu \mathrm{L}$ total volume) made on Plexiglass ${ }^{\circledR}$ and glued on top of the electrochemical cells. The introduced wells not only define precisely the exposed electrode area and separate the different two-electrode cells, but also act as bioreactor for the bacterial bioreporter assay. Electrical connections are made through a custom-made potentiostat multiplexer (Diagnoswiss S.A., Switzerland) that applies a common potential value to all the cells, while recording independently the current produced in each microfluidic cell. All potentials are reported with respect to the quasi-reference Ag electrode. All the assays were carried out at room temperature $\left(20 \pm 2{ }^{\circ} \mathrm{C}\right)$.

\subsection{Bacterial bioreporter preparation}

The measurement of arsenite was performed by using the arsenic reporter strain E. coli DH5a (pPROBE'arsR-ABS-RBS-LacZ, strain 2245) described by Wackwitz et al. (Wackwitz et al., 2008). This strain contains a plasmid in which the ars operon promoter is fused to the arsR and lacZ genes. In addition, the strain contains a chromosomal ars operon with genes for the arsenate reductase (ArsC) and the efflux pump (ArsB). To prepare the cell suspension for the assay, the E. coli strain was plated on Luria Broth (LB) agar medium containing $50 \mu \mathrm{g} / \mathrm{mL}$ of kanamycin at $37^{\circ} \mathrm{C}$ for $16 \mathrm{~h}$. A single pure colony was picked and regrown to stationary phase in $5 \mathrm{~mL}$ liquid LB medium plus kanamycin at $37^{\circ} \mathrm{C}$, which was then diluted 50 times in fresh antibiotic free LB medium and incubated until the culture turbidity (optical density at $600 \mathrm{~nm}$ ) was equal to 0.6 (i.e. cell concentration $\approx 6 \times 10^{8}$ cells $\mathrm{mL}^{-1}$ ). The cell culture was placed on ice, and immediately before use, was diluted two times with a 1x PBS solution (phosphate-buffered saline, $137 \mathrm{mM} \mathrm{NaCl}$, $2.7 \mathrm{mM} \mathrm{KCl}, 4.3 \mathrm{mM} \mathrm{Na}_{2} \mathrm{HPO}_{4}$ and $1.47 \mathrm{mM} \mathrm{KH}_{2} \mathrm{PO}_{4}, \mathrm{pH}=7$ ) and then used for the bioassays as indicated below.

\subsection{Arsenic bacterial bioreporter sensitivity assessment}

A series of sample assays with variable As(III) concentrations was prepared by mixing the appropriate volumes of $\mathrm{As}(\mathrm{III}) 10 \mu \mathrm{M}$ or $1 \mu \mathrm{M}$ standard solutions with a constant volume of the $E$. coli bioreporter suspension in a final volume of $100 \mu \mathrm{L}$. Immediately, $25 \mu \mathrm{L}$ of this $\mathrm{As}(\mathrm{III})-E$. coli solution were mixed inside the analysis well with $25 \mu \mathrm{L}$ of $10 \mathrm{mM}$ PAPG in $1 \times \mathrm{PBS}(\mathrm{pH}=7)$. Final $\mathrm{As}(\mathrm{III})$ concentrations tested ranged from $0.00625 \mu \mathrm{M}$ to $0.4 \mu \mathrm{M}$ (i.e. $0.47 \mathrm{ppb}-30 \mathrm{ppb}$ ). For all the assays, the final E. coli cells concentration $\approx 1 \times 10^{8}$ cells $\mathrm{mL}^{-1}$. The initial induction time of the experiments and the time equal to zero for the electrochemical detection of PAP was taken as the moment when the As(III) and cell solutions were mixed together. A triplicate of each sample was prepared and measured simultaneously to assure a better reliability of the results. All experiments were performed at room temperature $\left(20 \pm 2{ }^{\circ} \mathrm{C}\right)$. Note that the range of arsenic concentrations tested is far below the concentration at which arsenic becomes toxic for the bacterial bioreporter cells and would influence their growth rates (i.e. $1-2 \mathrm{mg} \mathrm{L}^{-1}$ ). Additionally, the employed E. coli cells are auxotrophic for thiamine, which was not present in the assay medium. Therefore, it is expected that the number of bioreporter cells is not changing during the incubation time of the assay, and is not a major factor explaining reporter signal variability in replicate assays.

\subsection{Arsenic bacterial bioreporter validation}

Three groundwater samples each of $250 \mathrm{~mL}$ were acidified with $5 \mathrm{~mL}$ of $5 \mathrm{mM} \mathrm{HNO}_{3}$ just after being extracted from different locations in Switzerland. For comparison purposes, samples were analyzed by atomic absorption spectroscopy (AAS) as described in the ASTM D2972-08 at the Service de la consommation et affaires vétérinaires (SCAV) of Sion, Switzerland. For arsenic bacterial bioreporter measurements, the protocol presented by Trang et al., (Trang et al., 2005) was followed, but a standard addition method was employed in order to take into account the matrix effects from these complex samples. Briefly, $120 \mu \mathrm{L}$ of the water sample (neutralized just before the analysis with a defined amount of sodium pyrophosphate) was mixed with $40 \mu \mathrm{L}$ of a PAPG solution $(25 \mathrm{mM}), 40 \mu \mathrm{L}$ of a cell suspension prepared as discussed above and a given volume ranging from 0 to $6 \mu \mathrm{L}(x)$ of an $\mathrm{As}(\mathrm{III})$ $10 \mu \mathrm{M}$ standard solution. In order to keep in all cases the same final volume of $206 \mu \mathrm{L}$, a defined volume $(y)$ of water was added (i.e. $x \mu \mathrm{L}+y \mu \mathrm{L}+120 \mu \mathrm{L}$ of sample $+40 \mu \mathrm{L}$ of PAPG $25 \mathrm{mM}+40 \mu \mathrm{L}$ cell suspension $=206 \mu \mathrm{L}$ ). After thoroughly mixing all the added components, $50 \mu \mathrm{L}$ of this solution were transferred to the analysis well to perform the electrochemical measurements. As in the previous case, the initial induction time of the experiments and the time equal to zero for the electrochemical detection of PAP was taken as the moment when the As(III) and cell solutions were mixed together. The final spiked As(III) standard concentrations in the sample were equal to $0,7.27,14.54$ and $21.82 \mathrm{ppb}$. A triplicate of each solution was prepared and measured simultaneously to assure a better reliability. An additional real sample taken from wells in the Pannonian Basin, Romania was also analyzed. In this case $3 \mathrm{~L}$ of the water sample were acidified with $0.2 \% \mathrm{HNO}_{3}$ and stored at $4{ }^{\circ} \mathrm{C}$ until it was analyzed. For the bacterial bioreporter assays, the sample was diluted three times and then analyzed as described above for the standard addition of groundwater samples from Swiss mountains. All experiments were performed at room temperature $\left(20 \pm 2{ }^{\circ} \mathrm{C}\right)$ in order to mimic on-site conditions, however complete temperature control and even temperature increase (e.g. to $37^{\circ} \mathrm{C}$ ) will provide a faster response time of the presented bioassay.

\section{Results and discussion}

For the electrochemical monitoring of the metabolic response of the bioreporter, it has to be noticed that both PAP and PAPG are electroactive species and can be oxidized electrochemically through a two-electron transfer leading to the same reaction product (i.e. p-iminoquinone, PIQ) as depicted in Fig. 2a. Despite the two species being present during the electrochemical detection of PAP, no interference is introduced since the electrochemical oxidation of PAPG takes place at higher potentials, as can be seen in Fig. 2b. Fig. 2b shows the cyclic voltammetry of PAPG that in the first scan presents only one irreversible anodic signal at around $0.55 \mathrm{~V}$ that corresponds to reaction II in Fig. 2a. In the backward scan a cathodic signal appears at lower potentials (c.a. $-0.1 \mathrm{~V}$ ) due to the electrochemical reduction of PIQ to form PAP (see reaction I in Fig. 2a), which is electrochemically oxidized during the consecutive second scan at around $0.05 \mathrm{~V}$. Therefore, by recording the current generated at a constant potential of $0.05 \mathrm{~V}$, only the production of PAP will be monitored, and can be interpreted as the 
a

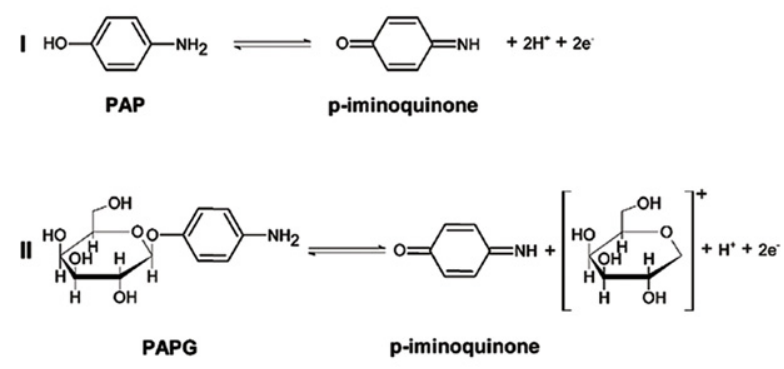

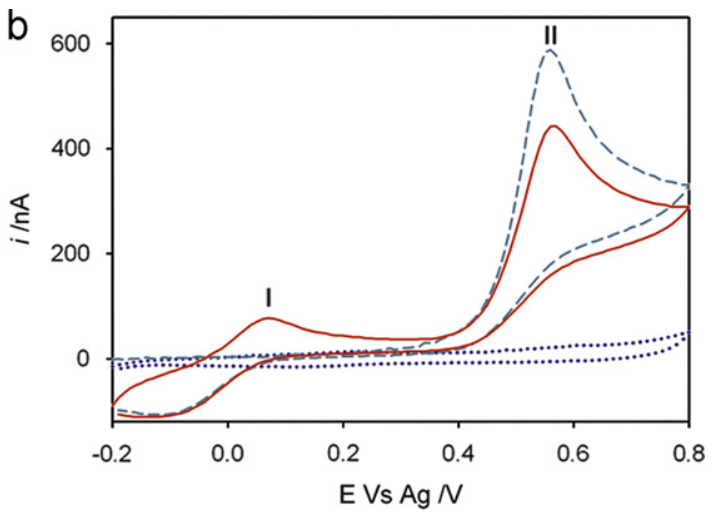

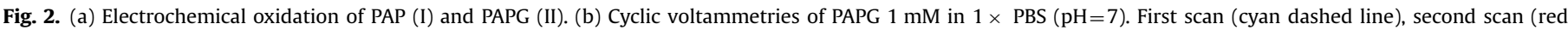

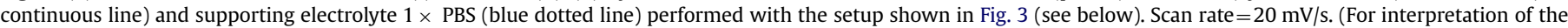
references to color in this figure legend, the reader is referred to the web version of this article.)
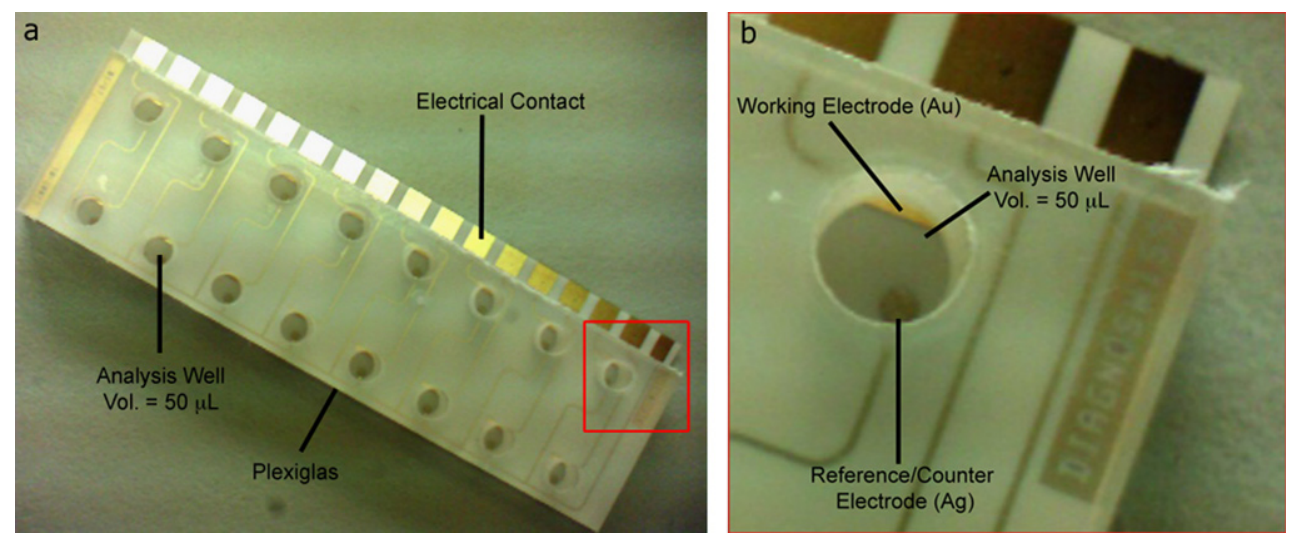

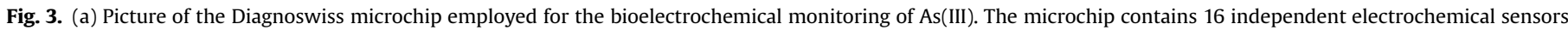
each one (b) consisting of a two-electrode setup (working electrode $=\mathrm{Au}$, counter/reference electrode $=\mathrm{Ag}$ ) and a well made in Plexiglas.

concentration of arsenic species that the bacteria bioreporter senses.

The electrochemical read-out of the bacterial bioreporter and the cyclic voltammetries presented in Fig. $2 b$ were performed by using a commercially available microchip composed by 16 wells of $50 \mu \mathrm{L}$ each, where 16 independent two-electrode cells are located (see Fig. 3). The latter makes this system a potentially highthroughput and also portable tool for the analysis of arsenite in water samples. As described above, the bioassay protocol requires simply mixing together the cell suspension, the water sample and the PAPG solution inside the analysis well and to record amperometrically the production of PAP. By following this protocol, we can obtain results similar to the ones shown in Fig. 4a, where the simultaneous amperometric detection of PAP is performed for 5 samples with different arsenite concentrations (i.e. 3.75, 7.5, 15 and $30 \mathrm{ppb}$ ). The range of concentration employed is very important since $10 \mathrm{ppb}$ is the highest limit of $\mathrm{As}(\mathrm{III})$ concentration accepted in potable water as defined by the WHO.

Moreover, quantification with bacterial bioreporters requires a comparison of the experimental signal with a calibration curve or a table of standardized values for different concentrations because variations in the induction conditions (e.g. time, temperature, assay format) as well as cell number and their activities will influence the produced assay signal. A multiplexed approach as the one proposed in this report can overcome such situation, thanks to the possible simultaneous analysis under the same conditions of the testing sample and standard solutions of the analyte. Finally, despite that the employed microchips can be cleaned after an assay and employed several times, it is advisable to use each electrochemical cell just once in order to avoid any contamination or electrode perturbations from previous experiments.

As can be seen from Fig. 4a, a clear current increase is observed as a function of the assay time, and in proportion to the concentration of As(III). Despite the blank test (i.e. no added As (III)) presenting a background progressive current increment, all the arsenite containing samples produced a higher signal than the background after a short period of time. Actually, the response time of the bacterial bioreporter can be defined as the time in which the arsenite-containing sample has a signal that is clearly differentiated from the background. For instance, an arsenite concentration of $7.5 \mathrm{ppb}(0.1 \mu \mathrm{M})$, which is lower than the acceptable limit of arsenite in water as defined by the WHO, can be clearly detected after a time between 25 to $50 \mathrm{~min}$ that in comparison with the state-of-the-art of arsenite bacterial bioreporters is at least twice faster for similar concentrations (Buffi et al., 2011). The shorter assay time may be due to using a more sensitive E. coli strain, to avoiding GFP maturation, and to the aforementioned advantages that the electrochemical techniques offers to the read-out of bacterial bioreporters. However, it is important to highlight that by encapsulating the bioreporter cells in agarose beads, it is possible to introduce them into a continuous monitoring microfluidic system and to store them for up to a month without loosing the arsenic detection capabilities at low concentrations (Buffi et al., 2011). The error bars shown in Fig. 4a represent the standard deviation of triplicates from each sample that were performed simultaneously. In some figures the error bars are not observed, since the size of the symbol employed is bigger than the size of the error bars. 

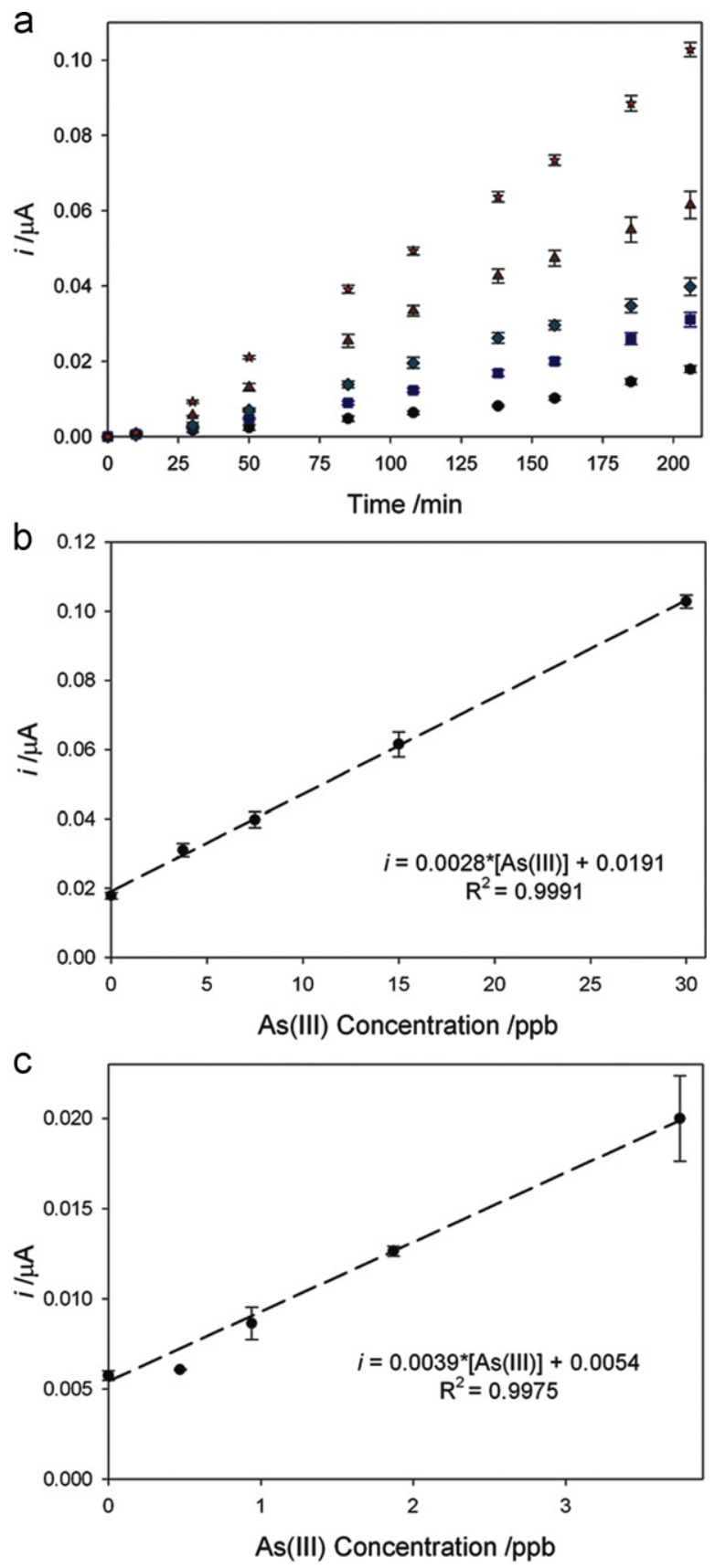

Fig. 4. (a) Amperometric detection of PAP as a function of time for different As(III) concentrations: $0 \mathrm{ppb}$ (black circles), $3.75 \mathrm{ppb}$ (filled blue squares), $7.5 \mathrm{ppb}(0.1 \mu \mathrm{M}$, filled cyan diamonds), $15 \mathrm{ppb}$ (filled brown triangles) and $30 \mathrm{ppb}$ (filled red stars). (b) Calibration curve for $\mathrm{As}(\mathrm{III})$ at high concentration range (3.75 $\mathrm{ppb}(\mathrm{RSD}=6.2 \%)$, $7.5 \mathrm{ppb}(\mathrm{RSD}=5.8 \%), 15 \mathrm{ppb}(\mathrm{RSD}=5.9 \%)$ and $30 \mathrm{ppb}(\mathrm{RSD}=1.8 \%)$ determined with the data obtained after 206 min of induction time (Fig. 4a). (c) Calibration curve for $\mathrm{As}(\mathrm{III})$ at low concentration range $(0.47 \mathrm{ppb}(\mathrm{RSD}=0.7 \%), 0.94 \mathrm{ppb}(\mathrm{RSD}=10.3 \%)$, $1.87 \mathrm{ppb}(\mathrm{RSD}=2.2 \%)$ and $3.75 \mathrm{ppb}(\mathrm{RSD}=11.8 \%)$ ) determined with the data obtained after $254 \mathrm{~min}$ of induction time (data not shown). The error bars represent the calculated standard deviation from a triplicate. (For interpretation of the references to color in this figure legend, the reader is referred to the web version of this article.)

Fig. 4a also shows that a better sensitivity can be obtained at longer assay times, which result in a higher current difference compared to the background. Therefore, by using the values shown in Fig. 4a at $206 \mathrm{~min}$ and $254 \mathrm{~min}$ for a lower concentration range (results not shown), the calibration curves presented in Fig. $4 \mathrm{a}$ and $4 \mathrm{~b}$ were constructed. Actually a very good linear relationship in the two different ranges of concentrations studied (i.e. $0.47 \mathrm{ppb}-3.75 \mathrm{ppb}$ and

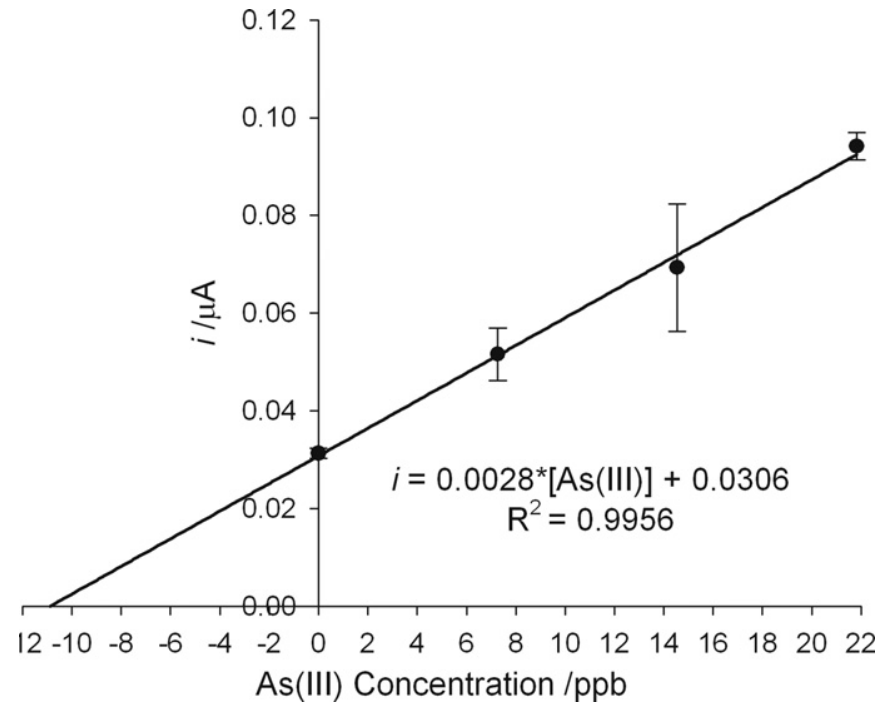

Fig. 5. Quantification of $A s(I I I)$ in a groundwater sample from Switzerland (Sample no. 3) employing the bacterial bioreporter by using the standard addition method. For more details please see the text and Table 1 . The error bars represent the calculated standard deviation from a triplicate.

Table 1

Arsenic species quantification in groundwater samples from Switzerland.

\begin{tabular}{lcc}
\hline Sample no. & \multicolumn{2}{l}{ As species concentration/ppb } \\
\cline { 2 - 3 } & Bioreporter $^{\mathrm{a}}$ & Reported (AAS) $^{\mathrm{b}}$ \\
\hline $\mathbf{1}$ & $4.8 \pm 0.4$ & $3.3 \pm 1.0$ \\
$\mathbf{2}$ & $7.7 \pm 1.6$ & $6.5 \pm 0.8$ \\
$\mathbf{3}$ & $18.7 \pm 1.2$ & $17.8 \pm 1.1^{\mathrm{c}}$ \\
$\mathbf{4}$ & $58.4 \pm 1.7$ & $66.0 \pm 6.6^{\mathrm{c}}$ \\
\hline
\end{tabular}

a This work. These values correspond to the arsenite equivalent concentration present in the samples.

${ }^{\mathrm{b}}$ Atomic absorption spectroscopy. These values correspond to the total amount of arsenic present in the sample.

${ }^{c}$ As reported by Swiss Federal Institute of Aquatic Science and Technology (EAWAG).

$3.75 \mathrm{ppb}-30 \mathrm{ppb}$ ) was found with the present methodology (see Figs. 4a and 4b). Moreover, the limit of detection (LOD) is equal to $0.8 \mathrm{ppb}$ (or $0.0105 \mu \mathrm{M}$ ), which to the best of our knowledge is probably one of the most sensitive detection limits reported for arsenic based whole-cell biosensors. As in Fig. 4a, the error bars represent the standard deviation of triplicates from each sample.

The faster and very sensitive response obtained in the present report is most likely due to the use of the pPROBE'arsR-ABS-RBSLacZ, strain 2245 that among others provides a faster reporter protein synthesis thanks to an improved lacZ ribosome binding site (Wackwitz et al., 2008). Further improvements can also be achieved by optimizing the detection chain of the bacterial bioreporters such as analyte diffusion, transport through the cell membrane, molecular recognition, assay temperature, etc. (Van Der Meer et al., 2004).

Finally, we have tested the present methodology with real samples by using the proposed methodology for the quantification of arsenic species in groundwater samples coming from Swiss mountains and the Pannonian Basin, Romania. With the aim to avoid any interference from the sample matrix, a standard addition method was implemented by spiking each water sample with a known concentration of arsenite, while keeping constant the concentration of arsenite in the original sample (see above). All samples were neutralized with sodium pyrophosphate just before the assay in order to work under optimal physiological conditions for the bioreporter bacteria $(\mathrm{pH}=6.9-7.2)$ and to avoid 
bioavailable arsenite depletion due to adsorption at iron hydroxide colloids formed at neutral pH (Trang et al., 2005). As in the previous case, all the components were mixed in the analysis well and the current at each electrochemical cell was recorded as a function of time. The average value of a triplicate of each solution is presented in Fig. 5 (i.e. for the groundwater sample no. 3), while its standard deviation represents the error bars. As can be seen in Fig. 5, the standard addition method produced a linear trend that by extrapolation to the $x$ axis gives the actual arsenite concentration of the sample. As the samples have been diluted during the biosensing processes (i.e. dilution factor equal to 120/206 for samples no. 1 to 3 and to $40 / 200$ for sample no. 4 ), the real arsenite concentration of sample no. 3 is equal to $18.7 \pm 1.2 \mathrm{ppb}$, which is in very good agreement with the values reported by AAS (i.e. $17.9 \pm 1.1 \mathrm{ppb}$ ). Similar results were obtained for the three other analyzed samples as summarized in Table 1 . The latter not only validates the present methodology, but also demonstrates that the present approach is a feasible strategy for the quantification of arsenic species in real samples. Still further improvement of the present bacterial bioreporter might be achieved by coupling it with functionalized magnetic beads to enhance the response and manipulation of the reporter cells (García-Alonso et al., 2010; Zhang et al., 2011).

\section{Conclusions}

The present work has revisited the electrochemical read-out of arsenic sensitive bacteria bioreporters showing that a high sensitivity and selectivity can be achieved in a short time. Therefore, monitoring of the water pollutant $\mathrm{As}(\mathrm{III})$ can be performed in a very high throughput way by using a portable chip containing 16 independent two-electrode cells. The outstanding sensitivity (i.e. $\mathrm{LOD}=0.8 \mathrm{ppb}$ ) and relatively short response time (i.e. 25$50 \mathrm{~min}$ for an As(III) concentration of $7.5 \mathrm{ppb}$, in comparison to previous bacterial bioreporter assays) of the employed methodology, is due to the combination of several factors such as, a more sensitive $E$. coli strain, a microchip format assay, the in situ amperometric detection of generated PAP and the advantages that electrochemical detection techniques can offer. Finally, the present approach was validated by analyzing groundwater samples coming from Swiss mountain areas and from Romania. Comparison with AAS shows a very good agreement between the two techniques corroborating the use of bacterial bioreporters for the quantification of $\mathrm{As}(\mathrm{III})$ in real samples. Furthermore, this report reinforces the possibility of coupling electrochemical and biological engineering methods for quantitative detection of different analytes in complex matrices.

\section{Acknowledgments}

The authors thank Dr. Joël Rossier and Dr. Pascal Willa from the Service de la consommation et affaires vétérinaires (SCAV) of Sion, Switzerland for kindly providing us the groundwater samples and their AAS analysis, as well as, Dr. Michael Berg from the Swiss Federal Institute of Aquatic Science and Technology (EAWAG). The financial support of this research provided by the NanoTera program through the LiveSense Project is also acknowledged.

\section{References}

Badihi-Mossberg, M., Buchner, V., Rishpon, J., 2007. Electroanalysis 19 (19-20), 2015-2028.

Baumann, B., Van Der Meer, J.R., 2007. Journal of Agricultural and Food Chemistry 55 (6), 2115-2120.

Beauchamp, E.M., Ringer, L., Bulut, G., Sajwan, K.P., Hall, M.D., Lee, Y.C., Peaceman, D., Ozdemirli, M., Rodriguez, O., Macdonald, T.J., Albanese, C., Toretsky, J.A., Uren, A., 2011. Journal of Clinical Investigation 121 (1), 148-160.

Biran, I., Babai, R., Levcov, K., Rishpon, J., Ron, E.Z., 2000. Environmental Microbiology 2 (3), 285-290.

Biran, I., Klimentiy, L., Hengge-Aronis, R., Ron, E.Z., Rishpon, J., 1999. Microbiology 145 (8), 2129-2133.

Brunt, R., Vasak, L., Griffioen, J., 2004. International Groundwater Resources Assessment Centre, Utrecht.

Buffi, N., Merulla, D., Beutier, J., Barbaud, F., Beggah, S., Van Lintel, H., Renaud, P., Roelof Van Der Meer, J., 2011. Lab on a Chip 11 (14), 2369-2377.

Daunert, S., Barrett, G., Feliciano, J.S., Shetty, R.S., Shrestha, S., Smith-Spencer, W. 2000. Chemical Reviews 100 (7), 2705-2738.

De la Calle, M.B., Emteborg, H., Linsinger, T.P.J., Montoro, R., Sloth, J.J., Rubio, R., Baxter, M.J., Feldmann, J., Vermaercke, P., Raber, G., 2011. Trends in Analytical Chemistry 30 (4), 641-651.

Eisler, R., 1988. U.S. Department Interior. pp. 1-65.

Feeney, R., Kounaves, S.P., 2002. Talanta 58 (1), 23-31.

García-Alonso, J., Fakhrullin, R.F., Paunov, V.N., 2010. Biosensors and Bioelectronics 25 (7), 1816-1819.

Jomova, K., Jenisova, Z., Feszterova, M., Baros, S., Liska, J., Hudecova, D., Rhodes, C.J., Valko, M., 2011. Journal of Applied Toxicology 31 (2), 95-107.

Melamed, D., 2005. Analytica Chimica Acta 532 (1), 1-13.

Melamed, S., Elad, T., Belkin, S., 2012. Current Opinion in Biotechnology 23 (1), 2-8.

Neufeld, T., Biran, D., Popovtzer, R., Erez, T., Ron, E.Z., Rishpon, J., 2006. Analytical Chemistry 78 (14), 4952-4956.

Paitan, Y., Biran, I., Shechter, N., Biran, D., Rishpon, J., Ron, E.Z., 2004. Analytical Biochemistry 335 (2), 175-183.

Pfeifer, H.R., Gueye-Girardet, A., Reymond, D., Schlegel, C., Temgoua, E., Hesterberg D.L., Chou, J.W., 2004. Geoderma 122 (2-4 SPEC. IIS.), 205-234.

Popovtzer, R., Neufeld, T., Biran, D., Ron, E.Z., Rishpon, J., Shacham-Diamand, Y. 2005. Nano Letters 5 (6), 1023-1027.

Popovtzer, R., Neufeld, T., Ron, E.z., Rishpon, J., Shacham-Diamand, Y., 2006. Sensors and Actuators B 119 (2), 664-672.

Rahman, M.M., Mukherjee, D., Sengupta, M.K., Chowdhury, U.K., Lodh, D., Chanda C.R., Roy, S., Selim, M., Quamruzzaman, Q., Milton, A.H., Shahidullah, S.M., Tofizur, R.M., Chakraborti, D., 2002. Environmental Science and Technology 36 (24), 5385-5394.

Ramanathan, S., Shi, W., Rosen, B.P., Daunert, S., 1997. Analytical Chemistry 69 (16) 3380-3384.

Ramanathan, S., Shi, W., Rosen, B.P., Daunert, S., 1998. Analytica Chimica Acta 369 (3), 189-195.

Ron, E.Z., 2007. Current Opinion in Biotechnology 18 (3), 252-256.

Ron, E.Z., Rishpon, J., 2010. Advances in Biochemical Engineering, Biotechnology 117, 77-84.

Scott, D.L., Ramanathan, S., Shi, W., Rosen, B.P., Daunert, S., 1997. Analytical Chemistry 69 (1), 16-20.

Siegfried, K., Endes, C., Bhuiyan, A.F.M.K., Kuppardt, A., Mattusch, J., Van Der Meer, J.R Chatzinotas, A., Harms, H., 2012. Environmental Science and Technology 46 (6) 3281-3287.

Stocker, J., Balluch, D., Gsell, M., Harms, H., Feliciano, J., Daunert, S., Malik, K.A., Van der Meer, J.R., 2003. Environmental Science and Technology 37 (20), 4743-4750.

Tauriainen, S., Karp, M., Chang, W., Virta, M., 1997. Applied and Environmental Microbiology 63 (11), 4456-4461.

Tauriainen, S., Karp, M., Chang, W., Virta, M., 1998. Biosensors and Bioelectronics 13 (9), 931-938.

Trang, P.T.K., Berg, M., Viet, P.H., Van Mui, N., Van Der Meer, J.R., 2005. Environmental Science and Technology 39 (19), 7625-7630.

Van Der Meer, J.R., Belkin, S., 2010. Nature Reviews Microbiology 8 (7), 511-522.

Van Der Meer, J.R., Tropel, D., Jaspers, M., 2004. Environmental Microbiology 6 (10) 1005-1020.

Wackwitz, A., Harms, H., Chatzinotas, A., Breuer, U., Vogne, C., Van Der Meer, J.R. 2008. Microbial Biotechnology 1 (2), 149-157.

WHO, 2010. World Health Organization, Geneva.

Wan, W., Pepping, T.J., Banerji, T., Chaudhari, S., Giammar, D.E., 2011. Water Research 45 (1), 384-392.

Zhang, D., Fakhrullin, R.F., Özmen, M., Wang, H., Wang, J., Paunov, V.N., Li, G., Huang, W.E., 2011. Microbial Biotechnology 4 (1), 89-97. 